\title{
Carp (Cyprinus carpio L.) lipid oxidation during cold storage
}

\author{
Andrzej S. Ochrem, Justyna Żychlińska-Buczek, Piotr Zapletal
}

Received - 02 February 2015/Accepted - 10 May 2015. Published online: 30 June 2015; @Inland Fisheries Institute in Olsztyn, Poland Citation: Ochrem A.S., Żychlińska-Buczek J., Zapletal P. 2015 - Carp (Cyprinus carpio) lipid oxidation during cold storage - Arch. Pol. Fish. 23: 101-106.

\begin{abstract}
After meat and dairy products, fish meat is one of the greatest sources of animal protein, but it is also probably the most susceptible to oxidation. The study material consisted of carp, Cyprinus carpio L., meat. The left and right sides of the fillet were divided into three parts, the head, abdomen, and tail. On the first day of the study, the anisidine value ranged from $0.21-1.70$, and did not differ significantly among the body parts. Peroxide values fluctuated frequently during the study. Lipid oxidation depended on the part of the fish the meat came from and the structure of the meat, either fillets or ground meat.
\end{abstract}

Keywords: carp, lipid, oxidation, peroxide value

\section{Introduction}

After meat and dairy products, fish meat is one of the greatest sources of animal protein. Annual carp catches and carp production in aquaculture are both growing. The world production of common carp, Cyprinus carpio L., in 2008 was nearly 3 million tons. Carp is also consumed traditionally in the countries of Central Europe (Mráz 2011), which is why its highest consumption in Poland is in December at Christmas. Carp is classified as either a fat 7.0-15.0\% (Kołakowska et al. 2002) or medium fat fish

A.S. Ochrem [ڤ”], J. Żychlińska-Buczek, P. Zapletal

Faculty of Animal Sciences

University of Agriculture in Cracow

Al. Mickiewicza 24/28, 30-059 Kraków, Poland

e-mail: a.ochrem@ur.krakow.pl
(Tkaczewska and Migdał 2012). The fat content in fish meat, however, depends on many factors, including nutrition, climate, species, origin (wild or farmed), and part of the fish the meat comes from. According to Aubourg et al. (2005) and Álvarez et al. (2009), fat content varies in different parts of fish.

Fish meat is probably the most susceptible to oxidation mainly because of its high level of unsaturated fatty acids (Sullivan and Budge 2012), and its shelf life is limited by enzymatic and microbial activity (Uçak et al. 2011). The oxidation of polyunsaturated fatty acids is catalyzed by heat, light, and enzymes, and leads to the formation of peroxides, aldehydes, ketones, and free radicals. Fish lipid oxidation is one of the major problems in fish processing, mainly through the loss of nutritional qualities and the unpleasant odor. The aim of this study was to evaluate changes in the lipid quality of $C$. carpio meat from different parts of the body that was stored under refrigeration conditions as fillet or minced meat.

\section{Material and methods}

The material consisted of twenty four carp $(32.74 \mathrm{~kg})$ obtained from the Experimental Station of the Agricultural University in Krakow (Mydlniki k. Krakowa, $\left.50^{\circ} 05^{\prime} 07.0^{\prime \prime} \mathrm{N} 19^{\circ} 50^{\prime} 23.4^{\prime \prime} \mathrm{E}\right)$. After delivery to the laboratory, the fish were gutted, filleted, and skinned, and then washed with tap water. Then the

\footnotetext{
(c) Copyright by Stanisław Sakowicz Inland Fisheries Institute in Olsztyn.

(C) 2015 Author(s). This is an open access article licensed under the Creative Commons Attribution-NonCommercial-NoDerivs License (http://creativecommons.org/licenses/by-nc-nd/3.0/).
} 
left and right side of the fillets were divided into three parts - the head, belly, and tail. The left fillets were placed in food containers at $4^{\circ} \mathrm{C}$, and the right fillets were grounded in a meat grinder (Zelmer, Poland) with a $3 \mathrm{~mm}$ mesh. This meat was also packed into uncovered food containers and stored in a refrigerator. Tests were performed every three days on two samples of meat from each body part on fillets and ground meat, for a total of 18 samples (six from the head, six from the belly, and six from the tail).

The lipids were extracted from fillets or ground meat using the Bligh and Dyer (1959) method. The extracts were stored in tightly sealed dark glass bottles at a temperature of $2-4^{\circ} \mathrm{C}$ until analysis (up to $1 \mathrm{~h}$ ).

The following were determined in the extracts:

a) Peroxide Value (PV) Analysis - PV was determined using the ferric thiocyanate method according to BN-74/8020-07. The method is based on the oxidation of ferrous ions into ferric ions by peroxides (present in rancid fat) and colorimetric assays of color complex.

b) Anisidine Value (AV) Analysis - AV was determined according to PN-93/A-86926. The method is based on the reaction of aldehydes (present in the sample - generated during the decomposition of hydroperoxides) with $\mathrm{p}$-anisidine in glacial acetic acid and the spectrophotometric measurement of the absorbance of yellow colored complex.

c) The fat content in extracts was determine according to $\mathrm{BN}-74 / 8020-07$.

d) Total oxidation value (Totox) was calculated $=(2.6$ $\mathrm{x}$ PV + AV) according to PN-93/A-86926.
The results were evaluated statistically. The results presented in the tables are the arithmetic averages of three parallel laboratory replicates. Statistical analysis was performed with Statistica 10.0 (StatSoft, Poland). The Kruskal-Wallis test was used to compare the differences among means. This was followed by the multiple comparisons medium rank test. Verification was performed at the level of $\mathrm{P}<0.05$.

\section{Results and discussion}

On the first day, the anisidine value (AV) ranged from 0.21 to 1.84 , and did not differ significantly among different parts of the body (Table 1). During the study it was found that AV increases during refrigerated storage of meat. The only statistically significant difference was recorded between the third and ninth days in ground meat from the head (0.55 to 3.80).

After nine days of the study, the mean AV ranged from 1.18 to 3.35 . The anisidine value is a secondary indicator of lipid oxidation, and is increasing with increasing aldehyde content (Zhang et al. 2013). Additionally, AV colorimetric determination depends on the concentration of secondary lipid oxidation products and their structural composition, and its value should not exceed 2 (Gokoglu et al. 2012). On the six day AV was below 2 only in the tail part of the fillets. This suggests that the maximum time of cold storage for carp meat is six days.

Changes in the peroxide value (PV) were larger and were also more statistically significant (Table 2). The peroxide value content is a primary indicator of

Table 1

Changes in anisidine value (AV) of carp (Cyprinus carpio) lipid during refrigerated storage

\begin{tabular}{lllll}
\hline \hline & Day 1 & Day 3 & Day 6 & Day 9 \\
\hline \hline Head fillet & $0.53 \pm 0.17^{\mathrm{Aab}}$ & $0.52 \pm 0.25^{\mathrm{Aa}}$ & $2.80 \pm 0.68^{\mathrm{Aa}}$ & $2.82 \pm 2.15^{\mathrm{Aa}}$ \\
Belly fillet & $1.84 \pm 0.29^{\mathrm{Aa}}$ & $4.58 \pm 1.93^{\mathrm{Ab}}$ & $2.52 \pm 1.26^{\mathrm{Aa}}$ & $3.13 \pm 2.97^{\mathrm{Aa}}$ \\
Tail fillet & $0.21 \pm 0.18^{\mathrm{Aab}}$ & $1.53 \pm 0.32^{\mathrm{Aab}}$ & $1.25 \pm 0.89^{\mathrm{Aa}}$ & $2.69 \pm 2.24^{\mathrm{Aa}}$ \\
Head ground meat & $0.51 \pm 0.10^{\mathrm{Ab}}$ & $0.55 \pm 0.23^{\mathrm{Aa}}$ & $3.80 \pm 1.97^{\mathrm{Ba}}$ & $1.18 \pm 0.22^{\mathrm{ABa}}$ \\
Belly ground meat & $1.70 \pm 0.28^{\mathrm{Aa}}$ & $1.25 \pm 0.29^{\mathrm{Aab}}$ & $2.26 \pm 1.45^{\mathrm{Aa}}$ & $2.44 \pm 1.37^{\mathrm{Aa}}$ \\
Tail ground meat & $1.11 \pm 0.24^{\mathrm{Aab}}$ & $0.95 \pm 0.50^{\mathrm{Aab}}$ & $3.27 \pm 0.50^{\mathrm{Aa}}$ & $3.35 \pm 3.13^{\mathrm{Aa}}$ \\
\hline \hline
\end{tabular}

Means in the same row with different superscript letters (ABC) and mean value in the same column with different superscript letters (abc) differ significantly $(\mathrm{P} \leq 0.05)$ 
Table 2

Changes in peroxide value (PV) $\mathrm{mEq}_{2} \mathrm{~kg}^{-1}$ of carp (C. carpio) lipid during refrigerated storage

\begin{tabular}{lllll}
\hline \hline & Day 1 & Day 3 & Day 6 & Day 9 \\
\hline \hline Head fillet & $2.26 \pm 0.57^{\mathrm{Aab}}$ & $2.48 \pm 0.34^{\mathrm{Aab}}$ & $6.49 \pm 1.06^{\mathrm{Aab}}$ & $2.29 \pm 0.88^{\mathrm{Aa}}$ \\
Belly fillet & $2.20 \pm 0.21^{\mathrm{Aab}}$ & $6.43 \pm 0.91^{\mathrm{Ba}}$ & $4.82 \pm 0.42^{\mathrm{ABa}}$ & $2.62 \pm 2.23^{\mathrm{ABa}}$ \\
Tail fillet & $1.95 \pm 0.64^{\mathrm{Aa}}$ & $2.32 \pm 0.18^{\mathrm{Aab}}$ & $39.47 \pm 5.49^{\mathrm{Bb}}$ & $18.49 \pm 2.05^{\mathrm{ABb}}$ \\
Head ground meat & $2.42 \pm 0.37^{\mathrm{ABab}}$ & $2.04 \pm 0.37^{\mathrm{Ab}}$ & $13.89 \pm 1.08^{\mathrm{Bab}}$ & $2.33 \pm 0.24^{\mathrm{ABa}}$ \\
Belly ground meat & $3.65 \pm 0.35^{\mathrm{Ab}}$ & $3.73 \pm 0.27^{\mathrm{Aab}}$ & $6.81 \pm 1.68^{\mathrm{Aab}}$ & $6.18 \pm 3.72^{\mathrm{Aab}}$ \\
Tail ground meat & $2.47 \pm 0.36^{\mathrm{Aab}}$ & $2.44 \pm 0.17^{\mathrm{Aab}}$ & $28.69 \pm 3.94^{\mathrm{Bb}}$ & $9.52 \pm 6.91^{\mathrm{ABab}}$ \\
\hline \hline
\end{tabular}

Means in the same row with different superscript letters (ABC) and mean value in the same column with different superscript letters (abc) differ significantly $(\mathrm{P} \leq 0.05)$

Table 3

Changes in Totox indicator of carp (C. carpio) lipid during refrigerated storage

\begin{tabular}{lllll}
\hline \hline & Day 1 & Day 3 & Day 6 & Day 9 \\
\hline \hline Head fillet & $6.40 \pm 1.49^{\mathrm{Aab}}$ & $6.96 \pm 1.06^{\mathrm{ABad}}$ & $19.66 \pm 2.97^{\mathrm{Bbc}}$ & $12.14 \pm 6.37^{\mathrm{ABab}}$ \\
Belly fillet & $7.55 \pm 0.81^{\mathrm{Aab}}$ & $21.30 \pm 4.17^{\mathrm{Bbc}}$ & $15.05 \pm 0.86^{\mathrm{ABb}}$ & $12.63 \pm 6.94^{\mathrm{ABab}}$ \\
Tail fillet & $5.28 \pm 1.72^{\mathrm{Aa}}$ & $7.56 \pm 0.69^{\mathrm{ABcd}}$ & $103.88 \pm 14.98^{\mathrm{Bc}}$ & $63.93 \pm 17.08^{\mathrm{ABa}}$ \\
Head ground meat & $6.81 \pm 1.05^{\mathrm{ABab}}$ & $5.84 \pm 1.05^{\mathrm{Ad}}$ & $39.90 \pm 2.81^{\mathrm{Bbc}}$ & $15.46 \pm 6.31^{\mathrm{ABb}}$ \\
Belly ground meat & $11.19 \pm 0.78^{\mathrm{ABb}}$ & $10.94 \pm 0.59^{\mathrm{Aac}}$ & $19.97 \pm 5.41^{\mathrm{Bab}}$ & $20.69 \pm 9.06^{\mathrm{ABab}}$ \\
Tail ground meat & $7.53 \pm 0.75^{\mathrm{ABab}}$ & $7.30 \pm 0.38^{\mathrm{Acd}}$ & $77.86 \pm 10.41^{\mathrm{Bac}}$ & $44.78 \pm 18.29^{\mathrm{ABab}}$ \\
\hline \hline
\end{tabular}

Means in the same row with different superscript letters $(\mathrm{ABC})$ and mean value in the same column with different superscript letters (abc) differ significantly $(\mathrm{P} \leq 0.05)$.

lipid oxidation products. Peroxide values after three days of storage in all parts of fish bodies were less than $8 \mathrm{mEq} \mathrm{O}_{2} \mathrm{~kg}^{-1}$ lipid, which means that the meat is acceptable for human consumption. But after six days, half of meat samples, especially those from the tail, were unfit for human consumption. In a previous study, Ochrem et al. (2014) used dielectric measurements and sensory evaluation to determine that the maximum meat carp storage period is eight days. In addition to the earlier results for assessing fat quality, it should be noted that carp fillets are fit for consumption for up to six days of cold storage. The results of the Totox indicator are shown in Table 3.

In a study on rainbow trout, Oncorhynchus mykiss (Walbaum), the PV on the first day was 0.86 $\mathrm{mEq} \mathrm{O} \mathrm{kg}^{-1}$ lipid, on the tenth it was $6.70 \mathrm{mEq} \mathrm{O}$ $\mathrm{kg}^{-1}$ lipid, and after twenty days value decreased to $4.67 \mathrm{mEq} \mathrm{O} \mathrm{kg}^{-1}$ lipid (Pezeshk et al. 2011). Pérez-Alonso et al. (2003) conducted a study on the quality of fat from different parts of the fish body. The PV of dorsal and ventral Atlantic pomfret, Brama brama (Bonnaterre), meat stored under refrigeration increased until day fifteen (1.83 to $27.26 \mathrm{mEq} \mathrm{O}_{2}$ $\mathrm{kg}^{-1}$ lipid and 2.39 to $17.98 \mathrm{mEq} \mathrm{O}_{2} \mathrm{~kg}^{-1}$ lipid, respectively). After this time, PV decreased to 5.52 $\mathrm{mEq} \mathrm{O}_{2} \mathrm{~kg}^{-1}$ lipid and $7.72 \mathrm{mEq} \mathrm{O} \mathrm{kg}^{-1}$ lipid.

Ježek and Buchtova (2012) studied frozen fillets of carp (C. carpio) and silver carp, Hypophthalmichthys molitrix (Val.). The peroxide value on the first day was higher in the carp meat $(2.31 \mathrm{mEq} \mathrm{O} 2$ $\mathrm{kg}^{-1}$ lipid compared to $1.73 \mathrm{mEq} \mathrm{O}_{2} \mathrm{~kg}^{-1}$ lipid). These values increased in the carp fillets until the fourth day, and then they began to decrease. A steady increase in peroxide value (with one day of lowered values) was noted in silver carp fillets. A similar relationship for the alteration of the peroxide value at the time of frozen storage $\left(-10^{\circ} \mathrm{C}\right)$ was reported by Aubourg and Medina (1999) for cod, Gadus morhua L., and haddock, Melanogrammus aeglefinus (L.). These values increased in cod from 2.0 to $7.8 \mathrm{mEq}$ $\mathrm{O}_{2} \mathrm{~kg}^{-1}$ lipid after nine months and then decreased after twelve months to $1.7 \mathrm{mEq} \mathrm{O}_{2} \mathrm{~kg}^{-1}$ lipid. In 
haddock, the relationship was as follows: the initial value increased from 1.8 to $30.5 \mathrm{mEq} \mathrm{O} \mathrm{kg}^{-1}$ lipid, and then it decreased to $0.8 \mathrm{mEq} \mathrm{O}_{2} \mathrm{~kg}^{-1}$ lipid. However, the authors did not note this relationship for fish stored at $-30^{\circ} \mathrm{C}$. Similar results were obtained in this study, when the PV value began to decrease after a few days. Hydroperoxide formation is higher than decomposition; therefore, its accumulation in tissue results in an increased peroxide value. When concentration is high following the breakdown into smaller molecules, the peroxide value decreases (Aubourg 1999).

Lipid content varied in different parts of the fish: $4.12 \%$ (head); $4.51 \%$ (belly); $5.03 \%$ (tail). The differences between the head and tail were statistically significant. No statistically significant correlation between PV, AV, Totox, and fat content in the different parts of the body were noted (Table 4). According to Hultin (1994) and Bartosz (2003), peroxidation affects mainly phospholipids, which are located in the cell membrane and are the most exposed to attack by free radicals. The level of fatty acids in cell membranes is low.

Aydin and Gokoglu (2014) conducted a study on frozen $\left(-20,-40,-80^{\circ} \mathrm{C}\right)$ anchovy, Engraulis encrasicolus (L.) stored for six months. The peroxide value increased at all temperatures, and the highest value was reached at $-20^{\circ} \mathrm{C}$ from an initial value of $2.32 \mathrm{mEq} \mathrm{O} \mathrm{kg}^{-1}$ lipid to $39.95 \mathrm{mEq} \mathrm{O} \mathrm{kg}^{-1}$ lipid, while the lowest value was noted at $-80^{\circ} \mathrm{C}$ in the final period at $22.61 \mathrm{mEq} \mathrm{O}_{2} \mathrm{~kg}^{-1}$ lipid. The anisidine value was also the lowest at $-80^{\circ} \mathrm{C}$ (14.92). Erkan and Özden (2008) found that evisceration exposes meat to more oxygen and accelerates oxidation. This is confirmed by their study of whole sardines,
Sardina pilchardus (Walbaum), the peroxide value of which on the first day was $3.34 \pm 0.13 \mathrm{mEq} \mathrm{O}$ $\mathrm{kg}^{-1}$ lipid and then it increased to $14.87 \pm 0.54 \mathrm{mEq}$ $\mathrm{O}_{2} \mathrm{~kg}^{-1}$ lipid after nine days. PV increased in gutted sardines stored at $4^{\circ} \mathrm{C}$ from $3.22 \pm 0.09 \mathrm{mEq} \mathrm{O}_{2} \mathrm{~kg}^{-1}$ lipid to $22.80 \pm 0.41 \mathrm{mEq} \mathrm{O}_{2} \mathrm{~kg}^{-1}$ lipid. Aranda et al. (2006) concludes that fillets are less susceptible to oxidation. Additionally, perhaps as a result of grinding, meat appears to lose naturally occurring antioxidants, which probably explains why the PV of minced meat was higher than that of fillets on the first day of the storage.

In a study on striped catfish, Pangasius hypophthalmus (Sauvage), fillets, the peroxide value was lower for raw fish $\left(1.35 \mathrm{mEq} \mathrm{O} \mathrm{kg}^{-1}\right.$ lipid) than fillets cooked in salted water $\left(21.87 \mathrm{mEq} \mathrm{O} \mathrm{kg}^{-1}\right.$ lipid). A similar correlation was found by Domiszewski et al. (2011) for anisidine values (0.81 to 3.52) and Totox ratios (3.51 to 47.26). Domiszewski (2013) also conducted a study on heating European sprat, Sprattus sprattus (L.), rainbow trout, O. mykiss, and herring, Clupea harengus membras L., meat. Minced fish were packed into glass containers and wrapped with aluminum foil. The author demonstrates that peroxide values were higher in the raw fillets. During heating $(15,30,60$, 90 and $120 \mathrm{~min}$ ), PV was reduced (when heated to 100 and $160^{\circ} \mathrm{C}$ ) or slightly increased and then decreased (when heated to $60^{\circ} \mathrm{C}$ ), but it did not exceed the initial value. This author also suggests that the antioxidant properties of fish meat and limited oxygen supply (foil cover) protect the meat from oxidation during heating. The peroxides are unstable and decompose into secondary products, and, according

Table 4

Pearson correlation between Peroxide Value (PV), Anisidine Value (AV), Total Oxidation Value (Totox) and fat content of fillet and ground meat carp (C. carpio) meat stored under refrigeration conditions. Data are not statically significant $(\mathrm{P}>0.05)$

\begin{tabular}{cllllllc}
\hline \hline & & \multicolumn{3}{c}{ Fillet } & \multicolumn{3}{c}{ Forcemeat } \\
\cline { 3 - 8 } & & PV & AV & Totox & PV & AV & Totox \\
\hline \hline Fat content (\%) & Head & -0.1644 & -0.3753 & -0.1643 & -0.2307 & -0.2983 & -0.2486 \\
& Belly & -0.0283 & -0.0537 & 0.0217 & 0.0277 & -0.0402 & 0.0170 \\
& Tail & -0.2004 & -0.2669 & -0.1661 & -0.2486 & -0.2254 & -0.2137 \\
\hline \hline
\end{tabular}


to Aidos (2002), this happens faster at higher temperatures.

Maybe under refrigeration conditions oxidation is to slow to utilize all the peroxides present in fish meat, which is why PV was detected in tail fillets and in abdomen and tail ground meat at high levels until the end of the study. Different results were obtained by Selmi et al. (2008) for cooking and canning tuna, Thunnus thynnus (L.), and sardine (S. pilchardus). The PV value in fresh tuna was $2.50 \pm 0.75 \mathrm{mEq} \mathrm{O}$ $\mathrm{kg}^{-1}$ lipid, and after cooking it was $10.82 \pm 0.88 \mathrm{mEq}$ $\mathrm{O}_{2} \mathrm{~kg}^{-1}$ lipid, while in sardine it was $8.14 \pm 0.49$ $\mathrm{mEq} \mathrm{O} \mathrm{kg}^{-1}$ lipid, and $10.18 \pm 1,14 \mathrm{mEq} \mathrm{O} \mathrm{kg}^{-1}$ lipid. These authors conclude that the lower increase of PV in the sardine can be explained by its lower fat content (1.16\%), and the addition of tomato sauce, which contains antioxidants that could reduce oxidation.

In a study on frozen $\left(-18^{\circ} \mathrm{C}\right)$ mackerel, Scomberomorus commerson (Lacépède), it was shown that the initial value of $\mathrm{PV}$ was $3.43 \mathrm{mEq} \mathrm{O}_{2}$ $\mathrm{kg}^{-1}$ lipid, and throughout the study it did not rise above $5 \mathrm{mEq} \mathrm{O} \mathrm{kg}^{-1}$ lipid, and AV remained almost unchanged (Nazemroaya et al. 2009). Majumdar et al. (2013) studied the use of cryoprotectants for freezing silver carp meat (H. molitrix). There were no statistically significant differences between minced stuffing before (5.65 mEq $\mathrm{O}_{2} \mathrm{~kg}^{-1}$ lipid) and after (5.59 $\mathrm{mEq} \mathrm{O}_{2} \mathrm{~kg}^{-1}$ lipid) washing. The $8 \mathrm{mEq} \mathrm{O}_{2} \mathrm{~kg}^{-1}$ lipid value is considered to be the upper limit of shelf life (Boran et al. 2006), and the ground meat treated with cryoprotectants exceeded this after 75 days of the study, while untreated meat did so after 45 days. Kolanowski (2010) suggests $10 \mathrm{mEq} \mathrm{O}_{2} \mathrm{~kg}^{-1}$ lipid as the upper limit for peroxide value.

The degree of lipid oxidation also depends on the type of ice used for fish meat storage. Losada et al. (2004) performed a study on sardine (S. pilchardus) storage in slurry ice, ozonized slurry ice, and flake ice. After two days of storage,. PV values were 1.89 , 3.28, and $2.08 \mathrm{mEq} \mathrm{O}_{2} \mathrm{~kg}^{-1}$ lipid, respectively. There were no statistically significant differences among these values. After three weeks, the values were: 35.35, 49.23, and $12.49 \mathrm{mEq} \mathrm{O}_{2} \mathrm{~kg}^{-1}$ lipid, and statistically significant differences were recorded between flake and ozonized slurry ice.

\section{Conclusions}

1. Fat oxidation in fish meat depends on which part of the body it is from and if it has been minced or left intact.

2. Peroxide values increase over time, but after six days they begin to decrease.

3. Anisidine values increases during storage under refrigerated conditions.

4. The shelf life of carp meat should be less than a week.

Acknowledgements. The study was conducted within the framework of the statutory research program of the University of Agriculture in Kraków, Faculty of Animal Sciences, Department of Cattle Breeding - DS 3245/KHB/13.

Author contributions. A.O. designed and performed the experiment, analyzed the data and performed statistical analysis, wrote the paper, made correction after review, J.B.-Ż. made laboratory analysis, P.Z. wrote the paper.

\section{References}

Aidos I., Lourenco S., Van der Padt A., Luten J.B., Boom R.M. 2002 - Stability of crude herring oil produced from fresh byproducts: influence of temperature during storage - J. Food. Sci. 67: 3314-3320.

Álvarez V., Medina I., Prego R., Aubourg S.P. 2009 - Lipid and mineral distribution in different zones of farmed and wild blackspot seabream (Pagellus bogaraveo) - Eur. J. Lipid. Sci Technol. 111: 957-966.

Aranda M., Mendoza N., Villegas R. 2006 - Lipid damage during frozen storage of whole jack mackerel (Trachurus symmetricus murphyi) - J. Food Lipids. 13: 155 -166.

Aubourg S.P. 1999 - Lipid damage detection during the frozen storage of an underutilized fish species - Food Res. Int. 32: 497-502.

Aubourg S.P., Medina I. 1999 - Influence of storage time and temperature on lipid deterioration during cod (Gadus 
morhua) and haddock (Melanogrammus aeglernus) frozen storage - J. Sci. Food Agric. 79: 1943-1948.

Aubourg S.P., Pińeiro C., Gallardo J.M., Barros-Velazquez J. 2005 - Biochemical changes and quality loss during chilled storage of farmed turbot (Psetta maxima) - Food Chem. 90: 445-452.

Aydin I., Gokoglu N. 2014 - Effects of temperature and time of freezing on lipid oxýdation in anchovy (Engraulis encrasicholus) during frozen storage - Eur. J. Lipid Sci. Technol. 116: 996-1001.

Bligh E.G., Dyer W.J. 1959 - A rapid method of total lipid extraction and purification - Can. J. Bioch. Physiol. 8: 911-917.

Boran G., Karacam H., Boran M. 2006 - Changes in the quality of fish oils due to storage temperature and time - Food Chem. 98: 693-698.

Domiszewski Z., Bienkiewicz G., Plust D. 2011 - Effects of different heat treatments on lipid quality of striped catfish (Pangasius hypophthalmus) - Acta Sci. Pol. Technol. Aliment. 3: 359-373.

Domiszewski Z. 2013 - Effect of heating fatty fish: Baltic herring (Clupea harengus membras), European sprat (Sprattus sprattus) and Rainbow trout (Oncorhynchus mykiss) on lipid oxidation and contents of eicosapentaenoic and docosahexaenoic acids - Int. J. Food Sci. Tech. 48: 786-793.

Erkan N., Özden Ö. 2008 - Quality assessment of whole and gutted sardines (Sardina pilchardus) stored in ice - Int. J. Food Sci. Tech. 43: 1549-1559.

Gokoglu N., Yerlikaya P., Kadir Topuz O. 2012 - Effects of tomato and garlic extracts on oxidative stability in marinated anchovy - J. Food Process Pres. 36: 191-197.

Hultin H.O. 1994 - Oxidation of lipids in Seafoods: Chemistry, Processing Techonology and Quality - Chapman and Hall, London, 49 p.

Ježek F., Buchtova H. 2012 - Shelf-life of freeze-thawed fillets of common carp (Cyprinus carpio L.) and silver carp (Hypophthalmichthys molitrix V.) packed under air 20th Int. Symp. “Animal Science Days”, Kranjska gora, Slovenia, Sept. $19^{\text {th }}-21^{\text {st }}$.

Kołakowska A., Olley J., Dunstan G.A. 2002 - Fish lipids - In: Chemical and Functional Properties of Food Lipids, CRC Press.

Kolanowski W. 2010 - Omega-3 LC PUFA Contents and Oxidative Stability of Encapsulated Fish Oil Dietary Supplements - Int. J. Food Prop. 13: 498-511.
Losada V., Barros-Velázquez J., Gallardo J.M., Aubourg S.P. 2004 - Effect of advanced chilling methods on lipid damage during sardine (Sardina pilchardus) storage - Eur. J. Lipid Sci. Technol. 106: 844-850.

Majumdar R.K., Deb S., Dhar B., Priyadarshini B.M. 2013 Chemical changes in washed mince of silver carp (Hypophthalmichthys molitrix) during frozen storage at $-20^{\circ} \mathrm{C}$ with or without cryoprotectants - J. Food Process Pres. 5: 952-961.

Mráz J. 2011 - Lipid Quality of Common Carp (Cyprinus carpio) in Pond Culture - Swedish University of Agricultural Sciences, Uppsala: 9-21.

Nazemroaya S., Sahari M.A., Rezaei M. 2009 - Effect of frozen storage on fatty acid composition and changes in lipid content of Scomberomorus commersoni and Carcharhinus dussumieri - J. Appl. Ichthyol. 25: 91-95.

Ochrem A., Zapletal P., Maj D., Gil Z., Żychlińska-Buczek J. 2014 - Changes in physical and dielectrical properties of carp meat (Cyprinus carpio) during cold storage - J. Food Process Eng. 2: 177-184.

Pérez-Alonso F., Arias C., Aubourg S.P. 2003 - Lipid deterioration during chilled storage of Atlantic pomfret (Brama brama) - Eur. J. Lipid Sci. Technol. 105: 661-667.

Pezeshk S., Rezaei M., Hosseini H. 2011 - Effects of turmeric, shallot extracts, and their combination on quality characteristics of vacuum-packaged rainbow trout stored at $4 \pm$ $1^{\circ} \mathrm{C}-$ J. Food Sci. 6: 387-391.

Selmi S., Monser L., Sadok S. 2008 - The influence of local canning process and storage on pelagic fish from tunisia: fatty acid profiles and quality indicators - J. Food Process Pres. 32: 443-457.

Sullivan J.C., Budge S.M. 2012 - Fish oil sensory properties can be predicted using key oxidative volatiles - Eur. J. Lipid Sci. Technol. 114: 496-503.

Tkaczewska J., Migdał W. 2012 - Comparison of slaughter yield, contents of basic nutrients, and heavy metals levels in muscles of carp (Cyprinus carpio L.) farmed in various regions in poland - ŻYWNOŚĆ. Nauka. Technologia. Jakość. 85: 180-189.

Uçak I., Özogul Y., Durmuş M. 2011 - The effects of rosemary extract combination with vacuum packing on the quality changes of Atlantic mackerel fish burgers - Int. J. Food Sci. Tech. 46: 1157-1163.

Zhang J., Wu D., Liu D., Fang Z., Chen J., Hu Y., Ye X. 2013 Effect of cooking styles on the lipid oxidation and fatty acid composition of grass carp (Ctenopharynyodon idellus) fillet - J. Food Biochem. 37: 212-219. 